\title{
Analisis Prinsip Muamalah terhadap Model Transaksi Jual Beli Online pada Aplikasi Bukalapak
}

\author{
Sofia Rachmayanti , Ifa Hanifia Senjiati, Titin Suprihatin \\ Program Studi Hukum Ekonomi Syariah, Fakultas Syariah, Universitas Islam Bandung \\ Jl. Tamansari No. 140116 \\ sofiarachmayanti@gmail.com, ifahanifasenjiani@unisba.ac.id, titinsuprihatin@unisba.ac.id
}

\begin{abstract}
Abstarct-The phenomenon of buying and selling online through programs that place lower prices makes interest in buying these items, cheap prices outside the normal price make people interested in participating in the program from BukalapakSerbuSeru. There is an imbalance between what is issued with what is received, people just need to pay 1 Rupiah, they have the opportunity to get cars, motorcycles, cellphones and other types of goods, even there are invaders who have won the goods they choose but do not receive the goods. Then it is necessary to conduct research to discuss the muamalah principle analysis of this transaction. This study aims to determine the muamalah principle of online buying and selling transaction models in electronic media, online buying and selling transaction models in the Bukalapak Seru Exciting application, and analysis of the muamalah principle of the transaction models in the BukuapakSerbu Exciting application. This research is qualitative, with a descriptive analytical approach. This type of research is a field (field research) with data collection methods: observation, interviews and literature studies. The results of this study are: First, the muamalah principle of the online sale and purchase transaction model in electronic media has fulfilled the nine muamalah principles. Second, the Transactions on the BukalapakSerbuSeru application have an unbalanced price, the delivery of goods that are not in accordance with the provisions, and there are other costs whose value is greater than the price being promoted. Third, the muamalah principle analysis of the online trading transaction model in the BukuapakSerbuSeru application that has fulfilled the muamalah principle, namely: mubah, halal, maslahah, benefits, willingness, and written principles. But what does not meet the muamalah principle is: the principle of balance, trust and justice.
\end{abstract}

Keywords-Muamalah

Principle, Buying

and SellingOnline, Bukalapak

Abstrak-Fenomena transaksi jual beli online melalui program yang menaruh harga lebih rendah membuat ketertarikan untuk membeli barang tersebut, harga murah diluar harga normal membuat masyarakat tertarik untuk mengikuti program dari Bukalapak Serbu Seru. Adanya ketidakseimbangan antara apa yang dikeluarkan dengan apa yang diterima, masyarakat cukup membayar 1 Rupiah sudah berkesempatan mendapatkan mobil, motor, handphone dan jenis barang lainnya, bahkan terdapat penyerbu yang sudah memenangkan barang yang dipilihnya namun tidak menerima barang tersebut. Maka perlu dilakukan penelitian untuk membahas analisis prinsip muamalah terhadap transaksi ini. Penelitian ini bertujuan untuk mengetahui prinsip muamalah terhadap model transaksi jual beli online pada media elektronik, model transaksi jual beli online pada aplikasi Bukalapak Serbu Seru, dan analisis prinsip muamalah terhadap model transaksi pada aplikasi Bukalapak Serbu Seru. Penelitian ini bersifat kualitatif, dengan pendekatan deskriptif analitis. Jenis penelitian adalah lapangan (field research) dengan metode pengumpulan data: observasi, wawancara dan studi literatur. Hasil penelitian ini bahwa: Pertama, prinsip muamalah terhadap model transaksi jual beli online pada media elektronik sudah memenuhi sembilan prinsip muamalah. Kedua, Transaksi pada aplikasi Bukalapak Serbu Seru terdapat harga yang tidak seimbang, penyerahan barang yang ditidak sesuai ketentuan, dan terdapat biaya-biaya lain yang nilainya lebih besar dari harga yang dipromosikan. Ketiga analisis prinsip muamalah terhadap model transaksi jual beli online pada aplikasi Bukalapak Serbu Seru yang sudah memenuhiprinsip muamalah yaitu: prinsip mubah,halal, maslahah, manfaat, kerelaan, dan tertulis. Namun yang tidak memenuhi prinsip muamalah yaitu: prinsip keseimbangan, amanah dan keadilan.

Kata Kunci-Prinsip Muamalah, Jual Beli Online, Bukalapak

\section{PENDAHULUAN}

Bukalapak merupakan salah satu marketplace yang sangat pesat perkembangannya di Indonesia. Mulai dari sistem yang aman dalam proses jual beli, memiliki komunitas yang solid dan berkembang di setiap kota diIndonesia, pencarian dana yang cepat bagi pelapak (penjual), peloporkeamanan transaksi di dunia jual beli online, dan masih banyak lagikelebihan-kelebihan Bukalapak lainnya. Bukalapak merupakan aplikasi Marketplace jual beli online di ponsel dengan mudah dan cepat yang semakin meningkat di Indonesia. Bukalapakmenawarkan berbagai macam produk-produk mulai dari produk fashion sampai dengan produk untuk kebutuhan sehari-hari. Bukalapak memiliki sistem yang aman dalam proses jual beli online, memiliki komunitas yang solid dan berkembang di setiap kota di Indonesia. Bukalapak juga menawarkan program-program untuk menarik konsumen salah satunya adalah gratis ongkir.

Selain program gratis ongkir, Bukalapak juga memiliki program menarik lainnya. Salah satunya adalah program terbaru dari Bukalapak yaitu Serbu Seru yang diselenggarakan dari bulan November 2018. Bukalapakserba seru merupakan fitur yang akan menjual barang-barang bernilai tinggi seperti handphone, jam tangan kendaraan, dan lainnya dengan beragam harga mulai dari Rp. 1 atau lebih. Pengguna harus membeli dengan harga tersebut lalu menyelesaikan pembayaran. Hanya terdapat beberapa penyerbu yang terpilih yang akan mendapatkan barang tersebut. Sedangkan bagi penyerbu 
yang meleset maka dana yang telah dibayar akan dikembalikan $100 \%$ ke saldo Dana.Dana merupakan fitur layanan dompet atau uang elektronik yang dapat digunakan sebagai alternatif metode pembayaran dan pengembalian di platform Bukalapak. Pembeli bisa memilih semua barang yang tertera di Serbu Seru dan membeli barang tersebut sebanyak-banyaknya. Serbu Seru akan diumumkan dalam jangka waktu 3 jam dari masa pemilihan barang. Serbu Seru setiap harinya mengadakan enam kali sesi pengundian, sesi pertama pukul 08:00 sesi kedua pukul 12:00 sesi ketiga pukul 15:00 sesi keempat pukul 18:00 sesi kelima pukul 21:00 dan terakhir sesi keenam pukul 00:00 Program terbaru dari Bukalapak ini yang membuat nama Bukalapak semakin berkibar.

Islam memberi kesempatan yang luas untuk mengembangkan suatu model bisnis baru, selama tidak melanggar aturan-aturan syariah. Bahwa hukum asal dalam transaksiadalah diperbolehkan kecuali terdapat nash yang melarangnya. Agar kegiatan muamalah seseorang sejalan dengan ketentuan syariat Islam, maka ia harus menyelaraskan dengan prinsip-prinsip muamalah yang digariskan dalam ajaran Islam.

\section{LANDASAN TEORI}

Prinsip muamalah adalah hal-hal pokok yang harus dipenuhi dalam melakukan aktivitas yang berkaitan dengan hak-hak kebendaan dengan sesama manusia. Agar kegiatan muamalah seseorang sejalan dengan ketentuan syariat Islam, maka ia harus menyelaraskan dengan prinsip-prinsip muamalah yang digariskan dalam ajaran Islam. Hal-hal yang menajadi prinsip dalam bermuamalah adalah

\section{Prinsip Mubah}

yaitu Ulama fikih sepakat, bahwa hukum asal dalam transaksi adalah diperbolehkan (mubah), kecuali terdapat nash yang melarangnya

2. Prinsip Halal,

Pada saat melakukan muamalah, benda yang akan di transaksikan harus suci zatnya sesuai dengan Quran surah Al-Maidah ayat 88.

\section{Prinsip Maslahah,}

adalah sesuatu yang ditunjukkan oleh dalil hukum tertentu yang membenarkan atau membatalkannya atas segala tindakan manusia dalam rangka mencapai tujuan syara, yaitu memelihara agama, jiwa, akal, harta benda, dan keturunan.

4. Prinsip Manfaat,

Benda yang ditransaksikan harus mempunyai nilai manfaat, baik manfaat yang dapat dirasakan secara langsung, seperti buah-buahan maupun manfaat yang tidak langsung, seperti bibit tanaman. Jadi, tidak dibenarkan melakukan transaksi terhadap benda yang akan mendatangkan kesia-siaan bagi para pihak yang berakad karena muamalah dalam Islam harus mengandung manfaat serta menghindari bentuk kesia-siaan.
5. Prinsip Kerelaan/Konsensualisme, Dalam kajian fikih muamalah, prinsip ini dikenal dengan istilah prinsip an-taradhin (saling rela).

6. Prinsip Keseimbangan,

Meskipun secara faktual jarang terjadi keseimbangan antara para pihak dalam bertransaksi, namun hukum perjanjian Islam tetap menekankan perlunya keseimbangan itu, baik keseimbangan antara apa yang diberikan dan apa yang diterima maupun keseimbangan dalam memikul resiko

7. Prinsip Amanah,

Asas amanah dimaksudkan, bahwa masing-masing pihak haruslah beritikad baik dalam bertransaksi dengan pihak yang lainnya dan salah satu pihak tidak diberikan mengeksploitasi ketidaktahuan mitranya

8. Prinsip Tertulis,

Prinsip lain yang tak kalah pentingnya dalam bermuamalah atau melakukan sebuah transaksi atau akad adalah prinsip tertulis, yakni setiap perjanjian yang dilakukan oleh pihak-pihak yang melakukan akad harus diwujudkan dalam bentuk tulisan atau tertulis

9. Prinsip Keadilan,

Keadilan adalah tujuan yang hendak diwujudkan oleh semua hukum. Dalam hukum Islam, keadilan langsung merupakan perintah Al-Quran yang menegaskan,

Jual beli online adalah transaksi yang dilakukan penjual dan pembeli secara online melalui media internet, tidak ada perjumpaan langsung antara pembeli dan penjual.

Transaksi mengunakan internet, penyediaan aplikasi permohonan barang oleh pihak penjual di website merupakan ijab dan pengisian serta pengiriman aplikasi yang telah diisi oleh pembeli merupakan qabul. Adapun barang hanya dapat dilihat gambarnya serta dijelaskan spesifikasinya dengan gamblang dan lengkap, dengan penjelasan yang dapat mempengaruhi harga jual barang. Setelah ijab qabul, pihak penjual meminta pembeli melakukan tranfer uang ke rekening bank milik penjual. Setelah uang diterima, si penjual baru mengirim barangnya melalui kurir atau jasa pengiriman barang. Transaksi seperti ini (jual beli online) mayoritas para Ulama menghalalkannya selama tidak ada unsur gharar atau ketidakjelasan, dengan memberikan spesifikasi baik berupa gambar, jenis, warna, bentuk, model dan yang mempengaruhi harga barang. 1

Akad jual belionline atau jual beli pesanan dalam fiqih Islam disebut as-salam, menurut bahasa penduduk hijaz, sedangkan bahasa penduduk iraq as-salaf. Kedua kata ini mempunyai makna yang sama, sebagaimana dua kata tersebut digunakan oleh Nabi, sebagaimana diriwayatkan bahwa Rasulullah ketika membicarakan akad bay'salam, beliau menggunakan kata as-salaf disamping as-salam, sehingga dua kata tersebut merupakan kata yang sinonim. 2

Secara etimologis, salam adalah salaf yaitu sesutau 
yang didahulukan. Dalam konteks ini, jual beli salam/salaf di mana harga/uangnya didahulukan, sedangkan barangnya diserahkan kemudian dapat dinyatakan pula pembiayaan dimana pembeli diharuskan untuk membayar sejumlah uang tertentu untuk pengiriman barang. Atau dalam kata lain pembayaran dalam transaksi salam dilakukan di muka.

Rukun dan syarat dalam jual beli onlinemerupakan akad salam dimana pesanan dengan membayar terlebih dahulu dan barangnya diserahkan kemudian.Salam pada prinsipnya sama dengan rukun dan salam pada jual beli, yakni ijab dan kabul. Jenis-jenis Jual Beli Online antara lain Transaksi Antar Bank, Cash On Deliver, Rekening Bersama. Sedangkan mekanisme jual beli online terdiri dari berbagai tahapan yaitu :

\section{Information sharing}

Merupakan proses paling awal dalam transaksi. Pada tahap ini, calon pembeli biasanya melakukan browsing di Internet untuk mendapatkan informasi tentang produk tertentu yang akan dibeli.

\section{Online Orders}

Merupakan tahap pemesanan dari calon pembeli yang tertarik dengan produk (barang atau jasa) yang ditawarkan.

3. Online Transaction

Suatu proses perdagangan yang dilakukan secara online. Untuk melakukan transaksi online, banyak cara yang dapat dilakukan. Misalnya melalui media internet seseorang dapat melakukan transaksi online dengan cara chating atau melalui video conference secara audio visual. Sedangkan transaksi lainnya seperti menggunakan e-mail, juga dapat dilakukan secara mudah.

\section{E-Payment}

Merupakan suatu sistem pembayaran yang dilakukan secara elektronik. Biasanya agar dapat memberikan jasa pembayaran secara online(online payment),lembaga keuangan sebagai perusahaan penerbit (issuer), sebelumnya perlu menjalin kerjasama dengan perusahaan penyedia jaringan (provider).

\section{HASIL DAN PEMBAHASAN}

Penulis melakukan observasi terhadap program Serbu Seru Bukalapak untuk menganalisis prinsip muamalah yang diterapkan di program tersebut sudah sesuai atau belum dengan sembilan prinsip Muamalah. Yaitu Prinsip Mubah, Prinsip Halal, Prinsip Maslahah, Prinsip Manfaat, Prinsip Kerelaan/Konsensualisme, dan Prinsip Tertulis. Dari enam prinsip tersebut sudah sesuai dengan prinsip muamalah yang dijalankan oleh Bukalapak Serbu Seru sesuai dengan yang penulis jelaskan pada pembahasan sebelumnya.

Tiga dari sembilan prinsip muamalah yang tidak terpenuhi oleh Bukalapak Program Serbu Seru diantaranya : Prinsip Keseimbangan, prinsip ini tidak seimbang antara harga yang dijual oleh Bukalapak dengan barang yang diterima oleh pemenang Serbu Seru. Prinsip Amanah, prinsip ini tidak terpenuhi oleh Bukalapak
Program Serbu Seru karena pada syarat dan ketentuan sudah dijabarkan oleh Bukalapak mekanisme penerimaan pemenang dimana 14 hari kerja namun pada fakta dilapangan banyak penyerbu lebih dari 1 bulan baru menerima barang Serbu Seru dan yang lebih fatalnya adalah banyak pemenang Serbu Seru yang hingga saat ini barangnya tidak dikirim dan tidak mendapatkan kejelasan dari pihak Bukalapak. Dan terakhir Prinsip Keadilan, prinsip ini tidak terpenuhi oleh Bukalapak Serbu Seru, karena program ini memberikan informasi dengan harga sangat murah untuk bisa mendapatkan barang-barang Serbu Seru. Akan tetapi penyerbu setidaknya mengeluarkan saldo Dana lebih dari yang tertera di informasi Bukalapak sesuai dengan penulis jabarkan di bab sebelumnya.

\section{SIMPULAN}

\section{A. Simpulan}

Berdasarkan hasil penelitian yang penulis jelaskan pada bab sebelumnya, maka dapat disimpulkan sebagai berikut :

1. Prinsip muamalah terhadap model transaksi jual beli onlinepada media elektronik sudah memenuhi dari sembilan prinsip-prinsip muamalah, yaitu: prinsip mubah, halal, mashlahah, manfaat, kerelaan/konsensualisme, keseimbangan, amanah, tertulis, dan keadilan.

2. Model transaksi jual beli online pada aplikasi Bukalapak Serbu Seru terdapat tiga yang tidak memenuhi dari prinsip muamalah yaitu: Prisnip keseimbangan,Prinsip Amanah; dan Prinsip Keadilan.

3. Analisis Prinsip muamalah terhadap model transaksi jual beli online pada aplikasi Bukalapak Serbu Seru enam yang sudah terpenuhi yaitu: Prinsip Mubah, Prinsip Halal, Prinsip Maslahah, Prinsip Manfaat, Prinsip Kerelaan/Konsensualisme, dan Prinsip Tertulis. Namun tiga prinsip yang tidak terpenuhi yaitu: Prinsip Keseimbangan; terdapat ketidakseimbangan antara apa yang dikeluarkan dengan apa yang diterima. Prisnip Amanah; tidak sesuai dengan perjanjian yang ditulis oleh Bukalapak. Prinsip Keadilan; terdapat biayabiaya lain yang nilainya lebih besar dari harga yang dipromosikan oleh Bukalapak. 
B. Saran

Setelah menyimpulkan hasil dari penelitian, maka penulis ingin mengajukan saran-saran yang penulis harapkan dapat bermanfaat. Berikut adalah saran-saran yang penulis ajukan:

1. Bagi masyarakat yang mengikuti undian-undian di marketplace seharusnya lebih selektif dalam mengikuti undian model tersebut. Lebih memperhatikan bahwa transaksi tersebut sudah benar atau malah melanggar aturan syariah.

2. Bagi pihak Bukalapak diharapkan untuk lebih teliti terhadap pemenang Serbu Seru, karena banyak pemenang dari Serbu Seru yang tidak dikirim barangnya dengan berbagai macam alasan dan mengkonfirmasi untuk pemenang yang terpilih agar mendapat kejelasan dari pihak Bukalapak.

3. Bagi pihak Bukalapak untuk pemenang yang sudah terpilih seharusnya tidak bisa mengikuti Serbu Seru kembali, agar banyak kesempatan masyarakat lain yang terpilih Serbu Seru. Atau lebih di kondisikan untuk bisa mengikuti program Serbu Seru agar lebih diperhatikan kembali para pemenang sehingga barangnya sampai sesuai dengan ketentuan yang sudah dijelaskan oleh Bukalapak

\section{DAFTAR PUSTAKA}

[1] Bukalapak www.bukalapak.com

[2] Hidayat, \& Enang. (2015). Fikih Jual Beli. Bandung: PT. Remaja Rosdakarya.

[3] Adam, P. (2017). Fikih Muamalah Maliyah : Konsep Regulasi dan Implementasi. Bandung: Rafika Aditama. 